http://journal.nafo.int

J. Northw. Atl. Fish. Sci., Vol. 7: 145-154

\title{
Factors Relating to the Reproductive Biology of Georges Bank Haddock (Melanogrammus aeglefinus) in 1977-83
}

\author{
William J. Overholtz \\ National Marine Fisheries Service, Northeast Fisheries Center \\ Woods Hole, Massachusetts 02543, USA
}

\begin{abstract}
Distribution, sexual maturity, spawning dates and temperature preferences of Georges Bank haddock (Melanogrammus aeglefinus L.) were investigated with data collected on spring bottom-trawl surveys in 1977-83. The results agree with earlier work that peak spawning occurs during late March or early April and that preferred bottom temperatures ranged from $4^{\circ}$ to $7^{\circ} \mathrm{C}$. The Northeast peak of Georges Bank appeared to be the most important spawning area, but the area to the east of the Great South Channel in depths less than $100 \mathrm{~m}$ was also important during some years. Length at $50 \%$ maturity averaged $37 \mathrm{~cm}$ for males and $40 \mathrm{~cm}$ for females, and a response to large incoming year-classes was noted. The stock was composed of about $37 \%$ mature individuals at age 2 and $90 \%$ at age 3 , but these percentages varied by sex and year. Sex ratios averaged 1.33:1 in favor of females during the period and were skewed in favor of females in every year.
\end{abstract}

\section{Introduction}

Although haddock (Melanogrammus aeglefinus L.) on Georges Bank have been the subject of intense research since the 1930's, most of the effort has been directed toward stock assessments, collection and publication of fisheries statistics and gear selectivity work (Clark et al., 1982). Some studies have addressed the biology and life history of this stock (Bigelow and Schroeder, 1953; Colton, 1955; Chase, 1955; Clark, 1959; Marak and Livingstone, 1970; Laurence and Rogers, 1976; Laurence et al., 1981), but the published information is not very extensive and analyses of time series of data are generally not available.

After a period of relative equilibrium and high yields during 1931-60, the stock collapsed rapidly after heavy exploitation by an international fishery in 1965 and 1966 (Clark et al., 1982). Abundance dropped to about $10 \%$ of former levels by 1973 and recruitment declined dramatically (Clark et al., 1982; Overholtz et al., 1986).

Density-dependent changes in growth were noted by Clark et al. (1982) for the Georges Bank stock. Compensatory growth responses have also been noted in several other haddock stocks (Raitt, 1933; Sonina, 1965; Templeman et al., 1978; Beacham, 1983). This suggests that changes in other important biological variables such as sexual maturity and fecundity, might also occur with fluctuations in stock size. This kind of information, along with other life history data, such as spawning distributions, temperature preference, spawning dates, and lengths at $50 \%$ maturity $\left(L_{50}\right)$, could be useful in stock assessment work, recruitment research studies and as a basis for management decisions.

\section{Materials and Methods}

Spring bottom-trawl survey cruises have been conducted by the Northeast Fisheries Center since 1968. Data for 1977-83 from Georges Bank (Strata 1-25, 29-30) (Fig. 1) were used in this study. The surveys were conducted in April and May by research vessels Albatross IV and Delaware II, utilizing a stratifiedrandom survey design with standard gear and procedures, Grosslein, 1969; Azarovitz, 1981). These surveys provide an excellent source of biological information for many species, but are particularly good for haddock, the species that the original survey design was centered upon. Catch curve analysis and catch-pertow indices indicate that haddock from Georges Bank are probably fully vulnerable to the survey gear at age 1 (Clark et al., 1982; Overholtz et al., MS 1983). This suggests that random samples from this survey should provide a reasonable perspective on the Georges Bank stock as a whole.

Haddock were measured to the nearest centimeter (fork length), scales were collected for age analysis, and the maturity stage of the fish was determined. A five-part scoring system, consisting of immature, developing, ripe, spent, and resting categories, was used to stage the sexual maturity of the specimens (Morse, MS 1979). This system is similar to, but not as extensive as, the one described in Templeman et al. (1978).

All mature fish, including those classified as resting, were used in analyses of the distribution of the stock. At the present time, stock abundance is low and growth rates have increased; there is no reason to believe that resting fish encountered on the survey will not be spawners or perhaps have already spawned 


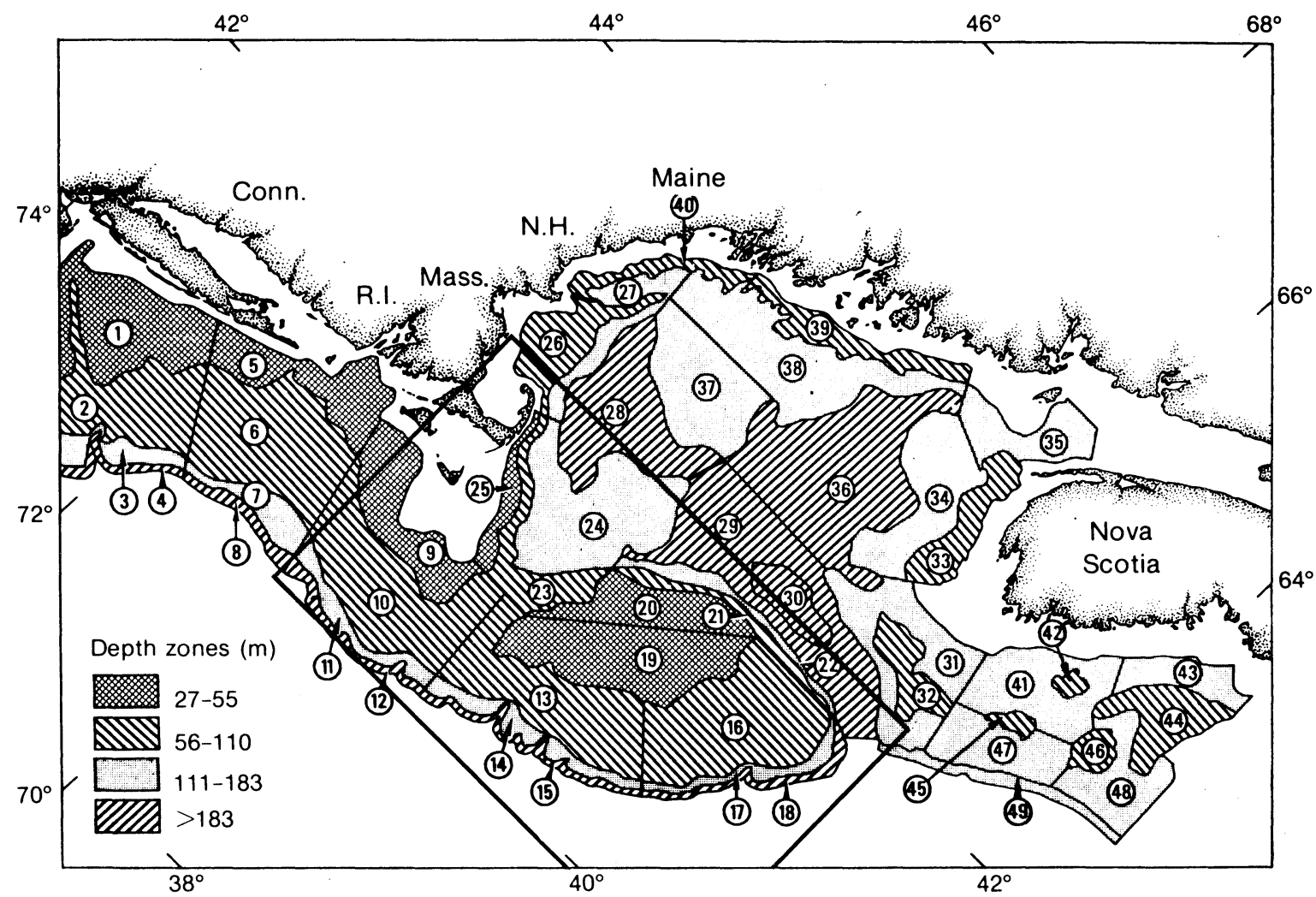

Fig. 1. Depth strata used in bottom-trawl surveys from Southern New England to the Gulf of Maine. (Georges Bank haddock strata are $13-25$ and $29-30$.)

during that season. Since analyses are meant to delineate large areas of spawning activity and not to pinpoint areas of active spawning in a given season, the use of all maturity stages is warranted. Distributions of all mature fish and of mature female fish only were plotted on an annual basis and in composite (females only). The female distribution plots were modified by including only those catches that comprised three or more fish. This was done to enhance the chances that the most important general areas of concentration would be discernable.

Annual and composite (1977-83) lengths at 50\% maturity were estimated for each sex, using logistic regression. A linear-fitting routine was utilized, and smoothed annual and composite curves by sex were produced with parameters from each logistic model. Sex ratios were calculated on the basis of the percentage of mature males and females in the 1977-83 survey catches. Only mature fish were utilized because they represent the reproductively active portion of the stock. The percentages of mature males and females were tested for equality by using a chi-square statistic (Sokal and Rohlf, 1969). Additionally, sex ratios of mature fish at ages 2-6 from the 1975 cohort and at ages 2-5 from the 1978 cohort were used in chi-square tests to determine if the number of mature male and female fish varied from a 1:1 ratio over the recruited life-span of these two cohorts.
The percentage of mature fish by age-group was calculated by summing the number of mature and immature fish collected for age analysis on an annual basis. The percentage of mature fish in the total survey catch (ages 1-9+) was also estimated.

Station location and oceanographic data were collected at each sampling site during each year. Bottom water temperatures (accurate to $0.1^{\circ} \mathrm{C}$ ) were collected at each station with an expendable bathythermograph. Percentage of mature haddock caught within each $1^{\circ} \mathrm{C}$ bottom temperature range was calculated. In addition, mean annual bottom temperature at haddock catch locations and the range of temperature in the survey area (Strata 13-25, 29-30 all stations) were determined. Plots of haddock catches over a $225 \mathrm{~m}$ range of depth and a $12^{\circ} \mathrm{C}$ range in temperature were also produced to help determine if these variables were important in determining the distribution of mature fish in the spring.

\section{Results}

Annual spawning period cannot be estimated with spring survey data due to the limited duration of the sampling, but inferences about the spawning season can be drawn. Maturity data for Georges Bank haddock from 1977 to 1983 indicate that the range of peak 
TABLE 1. Dates and numbers $(N)$ of haddock caught during spring bottom-trawl surveys on Georges Bank by maturity category, 1977-83.

\begin{tabular}{|c|c|c|c|c|c|c|}
\hline \multirow[b]{2}{*}{ Year } & \multicolumn{2}{|l|}{ Ripe } & \multicolumn{2}{|c|}{ Spent } & \multicolumn{2}{|c|}{ Resting } \\
\hline & Dates & $\mathrm{N}$ & Dates & $N$ & Dates & $N$ \\
\hline 1977 & 23-24 Apr & 20 & 23-30 Apr & 61 & 23-26 Apr & 53 \\
\hline 1978 & $28 \mathrm{Apr}, 25 \mathrm{May}$ & 125 & 21-22 Apr & 15 & 1-24 Apr & 191 \\
\hline 1979 & 4-6 Apr & 91 & 4-6 Apr & 64 & 8-11 May & 111 \\
\hline 1980 & $29 \mathrm{Apr}$ & 14 & $29 \mathrm{Apr}$ & 5 & 25 Apr-1 May & 106 \\
\hline 1981 & 26 Apr-8 May & 49 & 21-25 Apr & 38 & 25 Apr-9 May & 377 \\
\hline 1982 & $20 \mathrm{Apr}$ & 25 & 1-2 May & 5 & 18 Apr-2 May & 98 \\
\hline 1983 & $16 \mathrm{Apr}$ & 13 & 13-19 Apr & 27 & 13-19 Apr & 53 \\
\hline
\end{tabular}

spawning probably occurs from about the last two weeks in March until the third week in April, but usually in late March or early April (Table 1). Although ripe and spent fish were encountered during the survey in midApril, it appears that on average much of the spawning activity had taken place before this time. Most of the fish that were sampled during the last part of April and early May were resting, indicating that spawning was nearly completed by this time (Table 1 ).

Temperatures where mature (developing, ripe, spent, resting) haddock were encountered ranged from $3^{\circ}$ to $12^{\circ} \mathrm{C}$, but most fish were caught between $4^{\circ}$ and $7^{\circ} \mathrm{C}$ during 1977-83 (Table 2). Mean bottom temperatures where haddock were captured ranged annually from $4.6^{\circ}$ to $6.0^{\circ} \mathrm{C}$, resulting in a fairly narrow mean range where most of the mature fish were concentrated during the study period (Table 2). The mean bottom temperature for the entire period was $5.3^{\circ} \mathrm{C}$ at stations where haddock were captured and the range of water temperatures encountered at all stations was usually from about $4^{\circ}$ to $12^{\circ} \mathrm{C}$ (Table 2). When this analysis was repeated for developing and ripe fish only, there was little difference in the results. Thus, all mature fish were inhabiting water of much the same temperature in the survey period.

Although haddock were captured over a depth range from 40 to $200+\mathrm{m}$, most of the mature fish were confined to depths between 40 and $125 \mathrm{~m}$ and most of these fish were captured in less than $100 \mathrm{~m}$ (Fig. 2). Temperatures within the $4^{\circ}$ to $7^{\circ} \mathrm{C}$ range were frequently encountered at depths greater than $125 \mathrm{~m}$, but haddock were generally not available in those areas (i.e. strata 24, 29-30, etc.) (Fig. 1 and 2).

Plots of mature fish catches of both sexes suggest that spring distributions are highly variable on an annual basis (Fig. 3). In 1978, 1979, 1981, 1982 and 1983 , haddock were dispersed widely over much of Georges Bank, while, in 1977 and 1980, they were concentrated in stratum 16 and 23 and the eastern parts of strata 13,19 and 20 respectively (Fig. 3 ). In 1978, the distribution was characterized by a wide dispersion, with concentrations in stratum 16 and strata 13, 19, 20 and 23. In 1979, 1981 and 1982, although the fish were
TABLE 2. Distribution of mature haddock by $1^{\circ} \mathrm{C}$ temperature interval in samples from spring bottom-trawl surveys on Georges Bank, 1977-83. ( $N$ is number of haddock sampled. Mean tempeature is for stations where haddock were caught; temperature range is for all stations.)

\begin{tabular}{crrrrrrr}
\hline \hline $\begin{array}{c}\text { Bottom } \\
\text { temp. }\left({ }^{\circ} \mathrm{C}\right)\end{array}$ & \multicolumn{7}{c}{ Mature haddock distribution (\%) } \\
\cline { 2 - 8 } & 1977 & 1978 & 1979 & 1980 & 1981 & 1982 & 1983 \\
\hline $3.1-4.0$ & - & 8.1 & 1.4 & 0.5 & - & 23.2 & - \\
$4.1-5.0$ & 28.4 & 75.3 & 53.3 & 3.2 & 16.2 & 58.5 & 10.6 \\
$5.1-6.0$ & 60.9 & 14.2 & 35.3 & 44.4 & 51.4 & 13.7 & 54.9 \\
$6.1-7.0$ & 7.1 & 2.4 & 4.1 & 43.5 & 28.5 & 1.2 & 24.7 \\
$7.1-8.0$ & 3.6 & 0.0 & 4.5 & 2.8 & 0.0 & 0.0 & 5.1 \\
$8.1-9.0$ & 0.0 & 0.0 & 0.0 & 2.8 & 3.9 & 3.3 & 4.3 \\
$9.1-10.0$ & 0.0 & - & 0.0 & 1.4 & 0.0 & 0.0 & 0.0 \\
$10.1-11.0$ & 0.0 & - & 1.4 & 0.0 & 0.0 & 0.0 & 0.0 \\
$11.1-12.0$ & 0.0 & - & 0.0 & 0.0 & - & 0.0 & 0.4 \\
$12.1-13.0$ & - & - & - & 1.4 & - & 0.0 & 0.0 \\
\hline $\mathrm{N}$ & 197 & 409 & 484 & 216 & 512 & 241 & 235 \\
& & & & & & & \\
& & & & & & & \\
Mean temp. & 5.4 & 4.6 & 5.1 & 6.4 & 5.6 & 4.9 & 6.0 \\
Temp. & $4.5-$ & $3.7-$ & $3.6-$ & $3.8-$ & $4.1-$ & $4.0-$ & $4.4-$ \\
range & 11.3 & 8.7 & 12.0 & 12.3 & 10.8 & 12.1 & 12.4 \\
\hline
\end{tabular}

dispersed widely, there was some clumping around strata 16, 20 and 21 . In 1983, the fish seemed to congregate in stratum 16 and in strata 13 and 19 and to the east of the Great South Channel. The area comprising the western part of strata 13,19 and 20 and stratum 23 appeared to be an important concentration point for mature fish in 1978, 1980, and 1983.

When the catches of mature female fish are plotted, large general areas where spawning probably occurs become more apparent (Fig. 4). In 1978, 1981 and 1982, the mature females were dispersed widely, but primarily in stratum 16 in 1978 and 1982 and strata 19, 20 and 21 in 1981. The distribution of females was fairly compact in 1977, 1979 and 1980, with the Northeast Peak as the area of greatest concentration (Fig. 4). Again in 1978, 1980 and 1983, strata 13,19, 20 and 23 appeared also to be an important concentration point. A composite map of mature female fish catches suggests that the most important areas of concentration were along the $100 \mathrm{~m}$ contour, strata 16,20,21 and around strata 13, 19, 20 and 23 (Fig. 5). 

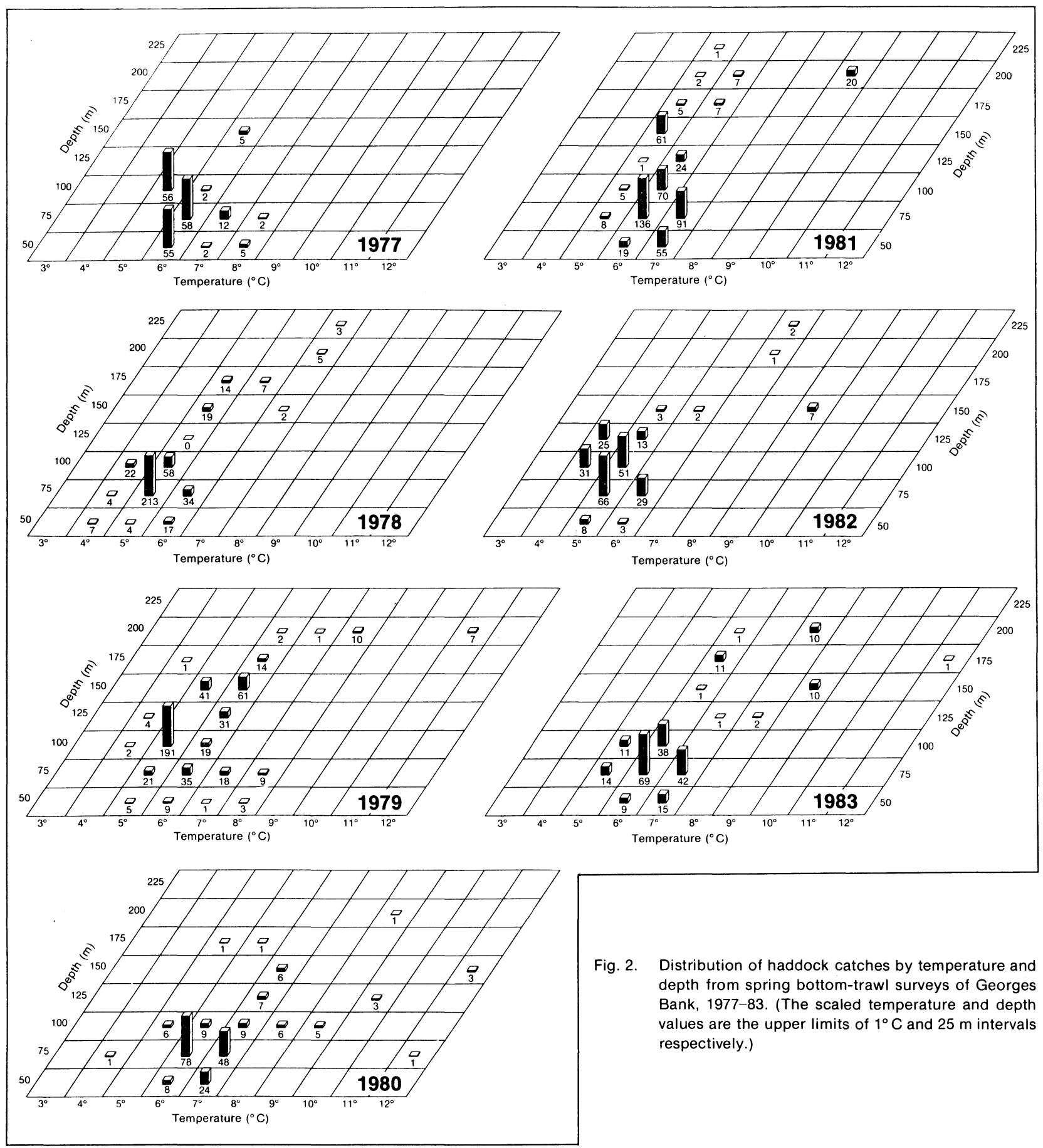

Fig. 2. Distribution of haddock catches by temperature and depth from spring bottom-trawl surveys of Georges Bank, 1977-83. (The scaled temperature and depth values are the upper limits of $1^{\circ} \mathrm{C}$ and $25 \mathrm{~m}$ intervals respectively.)

Mean lengths at $50 \%$ maturity were calculated for both males and females for the overall 1977-83 period (Fig. 6). The $L_{50}$ for males $(37 \mathrm{~cm})$ was less than that $(40 \mathrm{~cm})$ for females. Values ranges from 30 to $43 \mathrm{~cm}$ for males and from 37 to $43 \mathrm{~cm}$ for females. Length at $50 \%$ maturity generally increased for females from $37 \mathrm{~cm}$ in 1977 to $42 \mathrm{~cm}$ in 1980 (Fig. 7). After a drop to $38 \mathrm{~cm}$ in
1981 , the $L_{50}$ for females increased thereafter to $43 \mathrm{~cm}$ in 1983. For males, the $L_{50}$ increased from $32 \mathrm{~cm}$ in 1977 to $35 \mathrm{~cm}$ in 1979 . The 1980 estimate of $43 \mathrm{~cm}$ is probably spurious because sample size over the inflection point of the logistic curve was fairly small in that year. It was followed by two years at $37 \mathrm{~cm}$ in 1981 and 1982 (Fig. 7). In general, the $L_{50}$ for both sexes tended to increase 

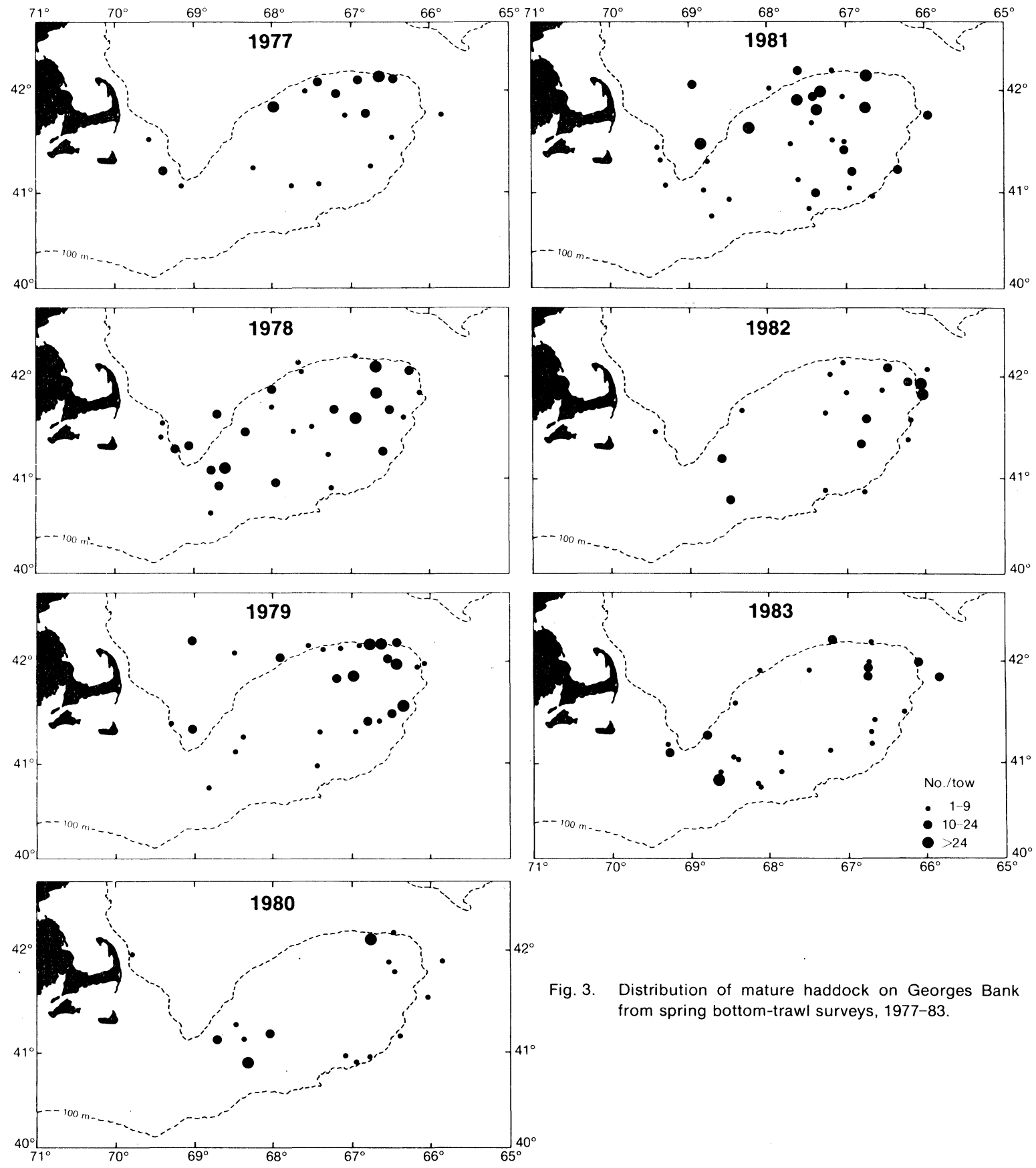

Fig. 3. Distribution of mature haddock on Georges Bank from spring bottom-trawl surveys, 1977-83.

from 1977 to 1983.

An average of about $77 \%$ of the total stock, as represented by survey catches, was mature over the 1977-83 period, but this ranged from 55 to 93\%, depending on the year (Fig. 8). Since a large proportion of the stock consisted of fish from the 1975 and 1978 year-classes, the percentage of mature fish was highly influenced by the maturity state of these two cohorts. The percentage of mature fish in the stock reached $93 \%$ in 1978 and $90 \%$ in 1981, due primarily to the maturation of the 1975 and 1978 year-classes respectively (Fig. 8). None of the age 1 fish sampled in 1977-83 were mature. The average percent mature at age 2 was $37 \%$, but this ranged from a high of $62 \%$ in 1977 to a low of $18 \%$ in 1979 (Table3). More males than females were mature at age $2(45 \%$ versus $33 \%)$ and at age $3(96 \%$ versus $91 \%)$. The range in age 2 maturity was greater for females from a low of $8 \%$ in 1979 to a high of $61 \%$ in 1977 . The percentage of mature age 2 fish was highest in 1983 for males and in 1977 for females, but the male percentage was nearly as high in 1977 . 

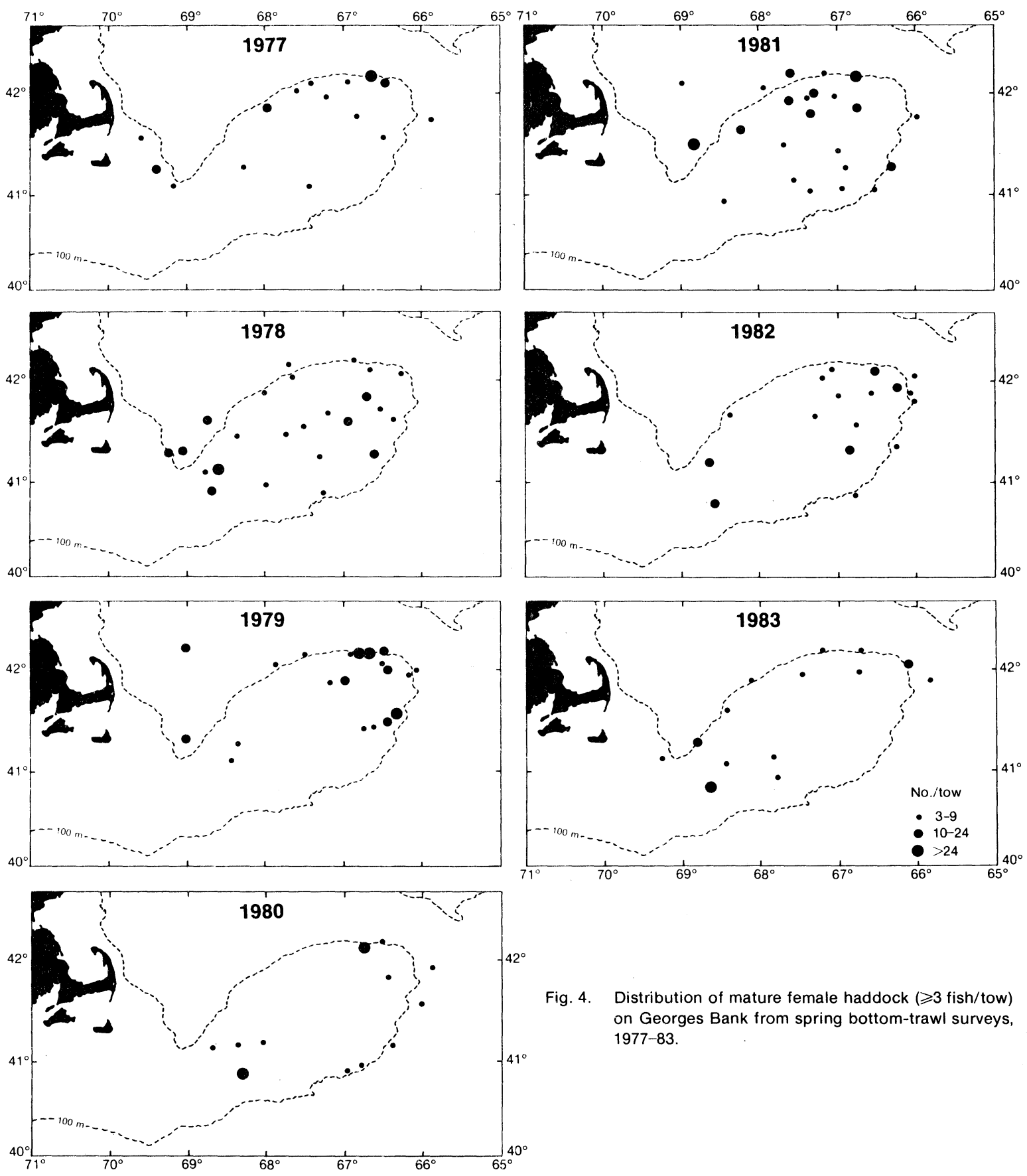

Fig. 4. Distribution of mature female haddock ( $\geqslant 3$ fish/tow) on Georges Bank from spring bottom-trawl surveys, 1977-83.

Sex ratios among mature fish in survey catches were skewed toward females in every year from 1977 to 1983. The average ratio for the time period was $1.33: 1$ in favor of females and the range was $1.15: 1$ to $1.52: 1$ (Table 4). Thus, on average, there were about $15 \%$ more females in the mature portion of the stock than males and over $20 \%$ more in 1980 . When the sex ratio of all fish (ages $1+$, immature and mature) was calcaulated, the ratio was further skewed toward females. A chi-square test for equality of sex ratios over the 1977-83 period showed that there was a significant difference $(P<0.01)$ between the number of mature males and females in the stock during most years and for all years combined (Table 4). Data from the 1975 and 1978 year-classes were also examined with a chi-square test to detect any differences in sex ratios among mature fish by cohort (Table 5). The results suggest that the 1975 and 1978 year-classes maintained a ratio in favor of females during and after age 2 in all years, but the difference was not significant. However, since there is no indication of 


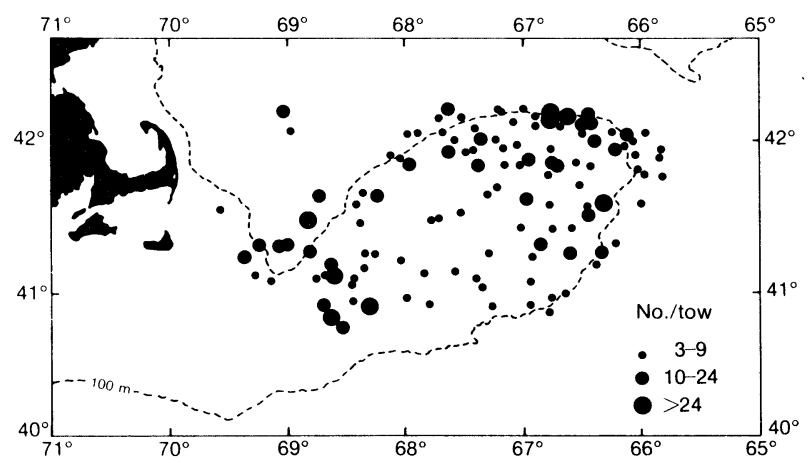

Fig. 5. Composite distribution of mature female haddock ( $\geqslant 3$ fish/ tow) on Georges Bank from spring bottom-trawl surveys, 1977-83.

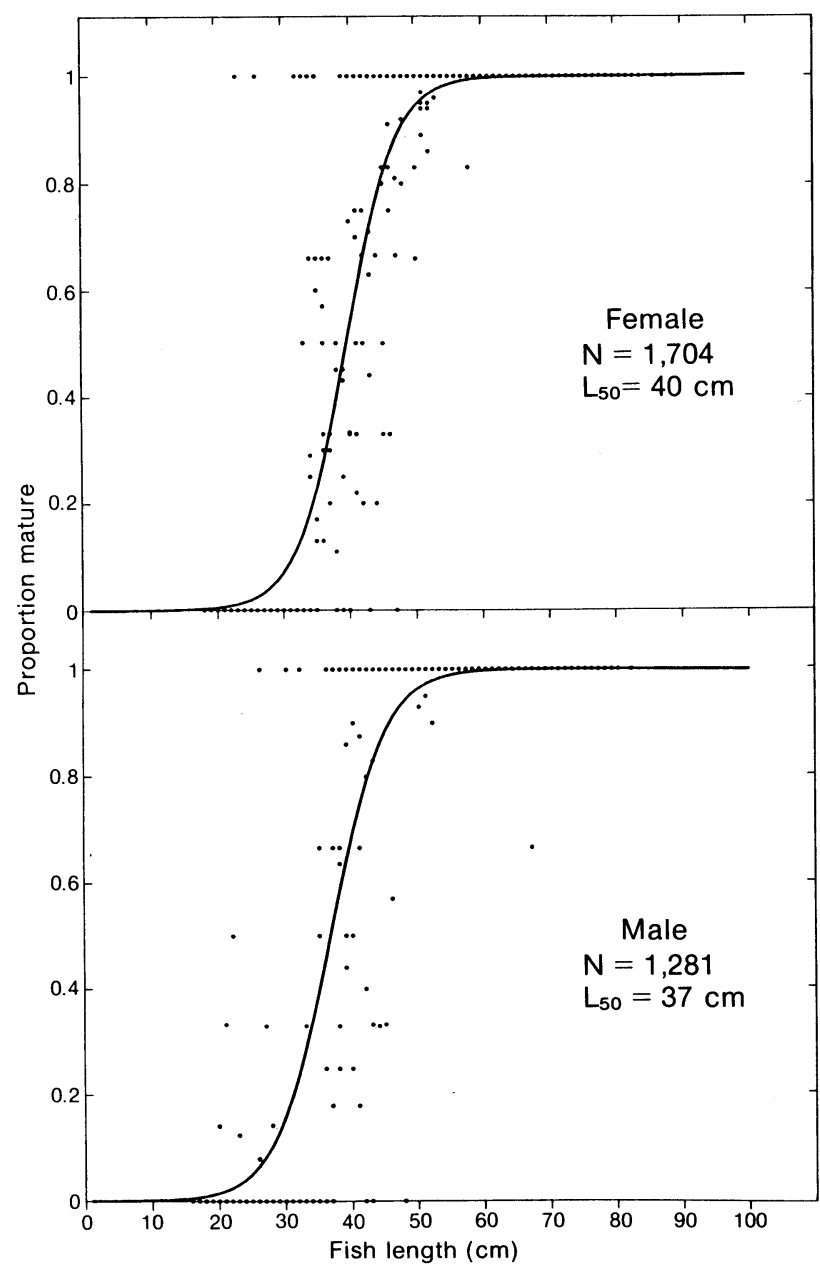

Fig. 6. Maturity ogives for female and male haddock from spring bottom-trawl surveys of Georges Bank, 1977-83, with plots of annual percent-at-length data.

differential mortality for mature fish by sex or year, the samples were combined and a highly significant chisquare statistic was obtained for both cohorts (Table $5)$.

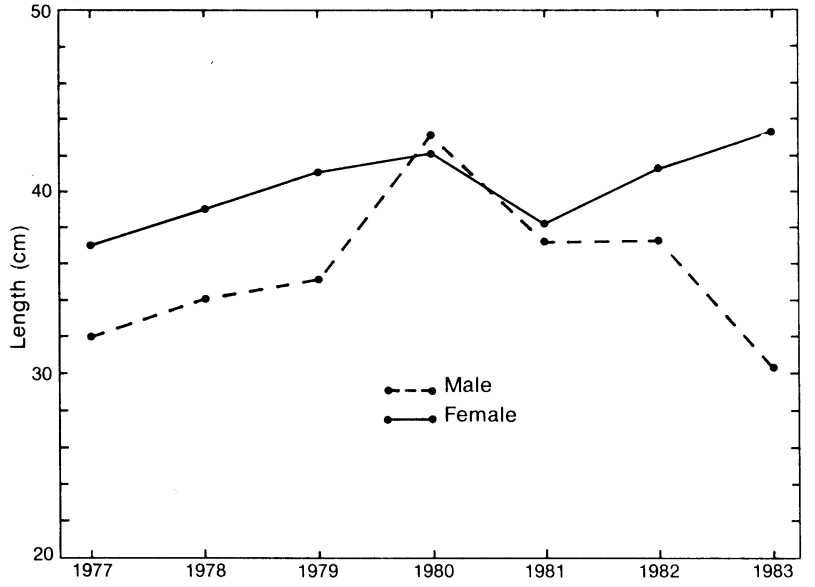

Fig. 7. Trends in length at $50 \%$ maturity of haddock on Georges Bank from spring bottom-trawl surveys, 1977-83.

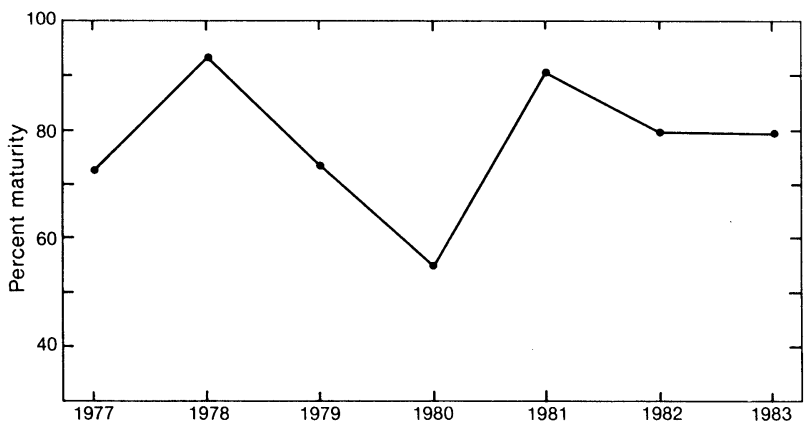

Fig. 8. Maturity status of the Georges Bank haddock stock, expressed as percent mature, from spring bottom-trawl surveys, 1977-83.

TABLE 3. Percentage mature haddock by age-group and sex in samples from spring bottom-trawl surveys of Georges Bank, 1977-83.

\begin{tabular}{lrrrrrrrr}
\hline \hline $\begin{array}{l}\text { Age } \\
\text { (yr) }\end{array}$ & 1977 & 1978 & 1979 & 1980 & 1981 & 1982 & 1983 & Mean \\
\cline { 2 - 9 } & \multicolumn{8}{c}{ Male } \\
& 0 & 0 & 0 & 0 & 0 & 0 & 0 & 0 \\
1 & 64 & 39 & 31 & 35 & 43 & 36 & 67 & 45 \\
2 & 100 & 99 & 80 & 100 & 98 & 92 & 100 & 96 \\
3 & 100 & 100 & 100 & 100 & 100 & 100 & 100 & 100 \\
4 & 100 & 100 & 100 & 100 & 100 & 100 & 100 & 100 \\
$5+$ & 100 & & & & & & &
\end{tabular}

\begin{tabular}{rrrrrrrrr}
\multicolumn{8}{c}{ Female } \\
1 & 0 & 0 & 0 & 0 & 0 & 0 & 0 & 0 \\
2 & 61 & 26 & 8 & 41 & 52 & 31 & 11 & 33 \\
3 & 100 & 99 & 71 & 100 & 94 & 67 & 39 & 81 \\
4 & 100 & 100 & 100 & 100 & 100 & 99 & 100 & 100 \\
$5+$ & 100 & 100 & 100 & 100 & 100 & 100 & 100 & 100
\end{tabular}

\section{Combined}

\begin{tabular}{rrrrrrrrr}
1 & 0 & 0 & 0 & 0 & 0 & 0 & 0 & 0 \\
2 & 62 & 30 & 18 & 37 & 47 & 30 & 36 & 37 \\
3 & 100 & 99 & 77 & 100 & 95 & 84 & 73 & 90 \\
4 & 100 & 100 & 100 & 100 & 100 & 99 & 100 & 100 \\
$5+$ & 100 & 100 & 100 & 100 & 100 & 100 & 100 & 100 \\
\hline
\end{tabular}


TABLE 4. Number of mature haddock $(N)$ and percent female $(F)$ in samples from spring bottom-trawl surveys of Georges Bank, 1977-83, with chi-square values and significance levels.

\begin{tabular}{lcccc}
\hline Year & $\mathrm{N}$ & $\% \mathrm{~F}$ & $x^{2}$ & $\mathrm{P}$ \\
\hline 1977 & 221 & 58.4 & 6.2 & $<0.05$ \\
1978 & 409 & 53.4 & 1.8 & $\mathrm{NS}$ \\
1979 & 492 & 58.9 & 15.7 & $<0.01$ \\
1980 & 217 & 60.4 & 9.3 & $<0.01$ \\
1981 & 512 & 58.2 & 13.8 & $<0.01$ \\
1982 & 243 & 57.6 & 5.6 & $<0.05$ \\
1983 & 235 & 55.3 & 2.7 & $\mathrm{NS}$ \\
Pooled & 2,329 & 57.4 & 50.5 & $<0.01$ \\
\hline
\end{tabular}

TABLE 5. Number of mature haddock $(N)$ and percent female $(F)$ by age-group for the 1975 and 1978 year-classes in samples from spring bottom-trawl surveys of Georges Bank, 197783 , with chi-square values and significance levels.

\begin{tabular}{|c|c|c|c|c|c|}
\hline $\begin{array}{l}\text { Year- } \\
\text { class }\end{array}$ & $\begin{array}{l}\text { Age } \\
\text { (yr) }\end{array}$ & $N$ & $\% F$ & $x^{2}$ & $\mathrm{P}$ \\
\hline \multirow[t]{6}{*}{1975} & 2 & 171 & 57.9 & 4.3 & $<0.05$ \\
\hline & 3 & 314 & 53.5 & 1.5 & NS \\
\hline & 4 & 329 & 57.1 & 6.7 & $<0.01$ \\
\hline & 5 & 109 & 57.8 & 2.7 & NS \\
\hline & 6 & 94 & 57.4 & 2.1 & NS \\
\hline & Pooled & 1,017 & 56.2 & 15.9 & $<0.01$ \\
\hline \multirow[t]{6}{*}{1978} & 2 & 166 & 54.2 & 1.2 & NS \\
\hline & 3 & 284 & 59.2 & 9.5 & $<0.01$ \\
\hline & 4 & 143 & 53.8 & 0.9 & NS \\
\hline & 5 & 118 & 54.2 & 0.9 & NS \\
\hline & 6 & - & - & & \\
\hline & Pooled & 711 & 56.1 & 10.7 & $<0.01$ \\
\hline
\end{tabular}

\section{Discussion}

The results of this study concerning spawning time are in accordance with a large body of information which has established that haddock have a clearly defined and relatively short spawning period. Although the onset of spawning may occur at different times due to the influence of temperature (Marak and Livingstone, 1970; Smith et al., MS 1981), peak hatching seems to occur on or about 21 April (Marak and Livingstone, 1970; W. Smith, Sandy Hook, New Jersey, pers. comm., 1985). Because it requires about 13 days for haddock eggs to hatch at $5^{\circ} \mathrm{C}$ (Bigelow and Schroeder, 1953), this would suggest that, on average, peak spawning probably occurs sometime around the first week in April.

The spring survey occurs during only a portion of the spawning season, hence it cannot be used to describe the whole chronology of spawning. However, in each year, many of the fish were already spent or in a resting condition by the third week in April (Table 1). In years such as 1979 and 1983, many ripe and spent fish were observed early in April, indicating that spawning had commenced prior to this time. Overall, the data suggest that peak spawning probably occurs sometime during the last week or two in March and the first 2 weeks in April. Other studies have suggested that this same period is most important for spawning (Marak and Livingstone, 1970; Colton et al.,1979).

Georges Bank haddock seem to have a fairly narrow range of preferred temperatures. Previous studies have suggested that maximum spawning occurs at bottom temperatures between $3.3^{\circ}$ and $5.6^{\circ} \mathrm{C}$ (Marak and Livingstone, 1970). Although the survey may have occurred after peak spawning in most years, the data suggest that the temperature regime which accompanied spawning activity in 1977-83 had probably changed little from previous times (Marak and Livingstone, 1970).

The temperature and depth analyses suggest that temperature is probably the more important controlling variable for determining haddock distribution in the spring. The variable annual distribution of mature haddock over the 1977-83 period indicates that spawning may not occur at the same sites on a yearly basis, but haddock may seek areas of shallow depth with the correct temperature regime for spawning. Numerous deeper water stations were sampled over the period, but few haddock were captured at these locations (Fig. $1,2,3)$. Strata $13,16,19,20,21$ and 23 probably contain fairly extensive grounds where conditions are suitable for spawning. Spawning in these areas presumably causes eggs to enter the clockwise circulatory pattern on Georges Bank, which serves as a mechanism to retain eggs and larvae on the bank (Buckley and Lough, 1987).

The distribution of mature female fish suggests that the Northeast Peak (strata 16,21 ) is still probably the most important spawning ground, with the area to the east of the Great South Channel (strata 13, 19, 20, 23) also an important congregation area at times. These areas are the same spawning grounds that were shown to be important in previous studies (Colton, 1955; Overholtz, 1985).

Georges Bank haddock mature at a smaller size than fish from other areas of the Northwest Atlantic (Templeman et al., 1978; Beacham, 1983). The trends that were noted in male and female $L_{50}$ values are probably the result of variable stock densities and growth patterns. Many studies have shown that size at maturity in fishes, and particularly in haddock, can be variable (Templeman and Bishop, 1979; Beacham, 1983; Stearns and Crandall, 1984; Echeverria, 1987).

These fish, at the southern limit of the range of the species, tend to mature at an earlier age than other 
stocks in the Northwest Atlantic. Fish from this stock are nearly fully mature at age 3. Beacham (1983) found that haddock cohorts on the Scotian Shelf were not fully mature until age 4, while cohorts from the Grand Bank were not fully mature until age 7 (Templeman et al., 1978).

Percent maturity at age 2 seems to have shown the most variation over the last several decades. Clark (1959) showed that about $21 \%$ of age 2 fish were mature during 1949-50, while Clark et al. (1982) reported that $46 \%$ of age 2 fish were mature in 1968-72. This percentage increased to $54 \%$ during the $1973-75$ period (Clark et al., 1982). The present study showed that the stock was about $37 \%$ mature at age 2 in 1977-83.

Possibly in response to low stock size, over $60 \%$ of the 1975 year-class were mature at age 2 , including $61 \%$ of the females. This percentage for females is high relative to that in other studies, i.e. $0 \%$ (Clark, 1959), and $28 \%$ for $1968-72$ and $34 \%$ for $1973-75$ (Clark et al, 1982). Similarly, when the large 1978 year-class reached age 2 in 1980, 41\% of the female fish were mature. This may indicate that a mechanism exists for a short-term response to declining or low stock density since maturation is related to growth.

Information on sex ratios for temperate fishes is fairly sparse, but a growing number of studies suggest that fish do not exhibit the typical mammalian pattern of a $1: 1$ ratio. Atlantic silversides (Menidia menidia) have size dependent sex ratios that are keyed to temperature during their larval development phase (Conover and Kynard, 1981; Conover and Fleisher, 1986). A study of northern anchovy (Engraulis mordax) showed that sex ratios were skewed toward males at ages 0-2 and then dominated by females thereafter (Parrish et al., 1986).

Several studies suggest that there may be a link between sex ratio and exploitation. A response to reduced density apparently occurred when sea lamprey populations were controlled in the Great Lakes. Sex ratios of lampreys switched from being heavily skewed in favor of males to the opposite (Torblaa and Westman, 1980). Coregonid stocks in Lake Michigan also were characterized by a majority of females during a period of heavy exploitation and low stock abundance in the 1960's (Brown, 1970).

It appears that females may be favored during the early life history of haddock in response to the low levels of abundance in recent years. The sex ratios of all the recent large year-classes including 1972, 1975, and 1978, were skewed in favor of females. Although the mechanism that is responsible for this phenomenon is not known, the response is consistent with other density-dependent changes, such as increased growth and reduced age at first maturity, which have occurred since the stock collapsed in the mid-1960's (Clark et al., 1982). An examination of earlier data from autumn 1963 and winter 1964 suggests that sex ratios of mature fish from that time period may have favored males. The sex ratio, in favor of males, was $1: 1.38$ in $1963(P<0.05)$ and $1: 1.17$ in 1964 (not significant). This suggests that there may be a relationship between density of fish and the sex ratio in this stock.

\section{Acknowledgements}

I thank my colleagues at the Northeast Fisheries Center who graciously collected the data for this study during 1977-83. I also appreciate the help and direction provided by R. Mayo, J. Burnett, L. O'Brien and S. Clark; they made this difficult process a little easier.

\section{References}

AZAROVITZ, T. R. 1981. A brief historical review of the Woods Hole laboratory trawl survey times series. Can. Spec. Publ. Fish. Aquat. Sci., 58: 62-67.

BEACHAM, T. D. 1983. Variability in size and age at sexual maturity of hadock (Melanogrammus aeglefinus) on the Scotian Shelf in the Northwest Atlantic. Can. Tech. Rep Fish. Aquat. Sci., 1168: 33 p.

BIGELOW, H. B., and W. C. SCHROEDER. 1953. Fishes of the Gulf of Maine. Fish. Bull. U. S., 53: 577 p.

BROWN, E. H. 1970. Extreme female predominance in the bloater (Coregonus hoyi) of Lake Michigan in the 1960's. In: Biology of coregonid fishes, p. 501-514. C. C. Lindsay and C. S. Wood (ed.), Univ. Manitoba Press, Winnipeg, Man.

BUCKLEY, L. J., and R. G. LOUGH. 1987. Recent growth, biochemical composition, and prey field of larval haddock (Melanogrammus aeglefinus) and Atlantic cod (Gadus morhua) on Georges Bank. Can. J. Fish. Aquat. Sci., 44: 14-25.

CHASE, J. 1955. Winds and temperature in relation to the brood strength of Georges Bank haddock. ICES J. Cons., 21: 17-24.

CLARK, J. R. 1959. Sexual maturity of haddock. Trans. Amer. Fish. Soc., 88: 212-213.

CLARK, S. H., W. J. OVERHOLTZ, and R. C. HENNEMUTH. 1982. Review and assessment of the Georges Bank and Gulf of Maine haddock fishery. J. Northw. Atl. Fish. Sci., 3: 1-27.

COLTON, J. B. 1955. Spring and summer distribution of haddock on Georges Bank. Spec. Sci. Rep. U.S. Fish. Wildl. Serv. - No. 156, 65 p.

COLTON, J. B., W. G. SMITH, A. W. KENDALL Jr., P. L. BERRIEN, and M. P. FAHAY. 1979. Principal spawning areas and time of marine fishes, Cape Sable to Cape Hatteras. Fish. Bull. US, 76: 911-915.

CONOVER, D. O., and B. E. KYNARD. 1981. Environmental sex determination: interaction of temperature and genotype in a fish. Science 213: 577-579.

CONOVER, D. O., and M. H. FLEISHER. 1986. Temperature- 
sensitive period of sex determination in the Atlantic silverside, Menidia menidia. Can. J. Fish. Aquat. Sci., 43: 514-520.

ECHEVERRIA, T. W. 1987. Thirty-four species of California rockfishes: maturity and seasonality of reproduction. Fish. Bull. US, 85: 229-250.

GROSSLEIN, M. D. 1969. Groundfish survey program of BCF Woods Hole. Comm. Fish. Rev., 31(8-9): 22-35.

LAURENCE, G. C., and C. A. ROGERS. 1976. Effects of temperature and salinity on comparative embryo development and mortality of Atlantic cod (Gadus morhua L.) and haddock (Melanogrammus aeglefinus L.). ICES J. Cons., 36: 220-228.

LAURENCE, G. C., A. S. SMIGIELSKI, T. A. HALAVIK, and B. R. BURNS. 1981. Implications of direct competition between larval cod (Gadus morhua) and haddock (Melanogrammus aeglefinus) in laboratory growth and survival studies at different food densities. ICES Rapp. Proc.Verb., 178: 304-311.

MARAK, R. R., and R. LIVINGSTONE. 1970. Spawning dates of Georges Bank haddock. ICNAF Res. Bull., 7: 56-58.

MORSE, W. W. MS 1979. An analysis of maturity observations of 12 groundfish species collected from Cape Hatteras, North Carolina to Nova Scotia in 1977. US Nat. Mar. Fish. Ser., Sandy Hook Lab., Ref. Doc., No. 79-32, 21 p.

OVERHOLTZ, W. J., S. H. CLARK, and D. Y. WHITE. MS 1983. A review of the status of the Georges Bank and Gulf of Maine haddock stocks for 1983. US Nat. Mar. Fish. Serv., Northeast Fisheries Center, Woods Hole, Lab. Ref. Doc. No. 83-23, $31 \mathrm{p}$.

OVERHOLTZ, W. J. 1985. Seasonal and age-specific distribution of the 1975 and 1978 year-classes of haddock on Georges Bank. NAFO Sci. Coun. Studies, 8: 77-82.

OVERHOLTZ, W. J., M. P. SISSENWINE, and S. H. CLARK. 1986. Recruitment variability and its implication for man- aging and rebuilding the Georges Bank haddock (Melanogrammus aeglefinus) stock. Can. J. Fish. Aquat. Sci., 43: 748-753.

PARRISH, R. H., D. L. MALLICOATE, and R. KLINYBEIL. 1986. Age dependent fecundity number of spawnings per year, sex ratio, and maturation stages in northern anchovy (Engraulis mordax). Fish. Bull. US, 84: 503-518.

RAITT, D. S. 1933. The fecundity of the haddock. Fish. Bd. Scot. Sci. Invest. 1932 (1), 42 p.

SMITH, W. G., P. L. BERRIEN, D. G. MCMILLIAN, and A. WELLS. MS 1981. The distribution abundance, and production of Atlantic cod and haddock larvae off the northeastern United States in 1978-79 and 1979-80. ICES C.M. Doc., No. G:52, 16 p.

SOKAL, R. R., and F. J. ROHLF. 1969. Biometry. W. H. Freeman and Co., San Francisco, CA, 776 p.

SONINA, M. A. 1965. Relationship between the growth rate and population density of haddock in the Barents Sea. ICNAF Spec. Pub., 6: 565-570.

STEARNS, S. C., and R. E. CRANDALL. 1984. Plasticity for age and size at sexual maturity: a life history reponse to unavoidable stresss. In: Fish Reproduction Strategy and Tactics, G. W. Potts and R. J. Wooten (ed.), London Academic Press, Chapter 2, p. 14-33.

TEMPLEMAN, W., V. M. HODDER, and R. WELLS. 1978. Sexual maturity and spawning in haddock, Melanogrammus aeglefinus, of the southern Grand Bank. ICNAF Res. Bull., 13: $53-65$.

TEMPLEMAN, W., and C. A. BISHOP. 1979. Sexual maturity and spawning in haddock Melanogrammus aeglefinus, of St Pierre Bank. ICNAF Res. Bull., 14: 77-83.

TORBLAA, R. L., and R. W. WESTMAN. 1980. Ecological impacts of lampricide treatments on sea lamprey (Petromyzon marinus) ammocoetes and metamorphosed individuals. Can. J. Fish. Aquat. Sci., 37: 1835-1850. 